\title{
Oxidative Stress, Chromium-Resistance and Uptake by Fungi: Isolated from Industrial Wastewater
}

\author{
Amina Elahi', Abdul Rehman ${ }^{1 *}$. \\ ${ }^{1}$ University of the Punjab - Microbiology and Molecular Genetics, Lahore, Pakistan.
}

\begin{abstract}
Trichosporon asahii and Rhodotorula mucilaginosa isolated from wastewater effluents were identified as chromiumresistant yeasts. $\mathrm{Cr}(\mathrm{VI})$ concentrations at $8 \mathrm{mM}$ and $6 \mathrm{mM}$ were inhibitory for $\mathrm{R}$. mucilaginosa and $\mathrm{T}$. asahii. Remarkably elevated GSH (69.88 \pm 10.01$)$ and GSSG (11.24 \pm 0.96$)$ was observed under metal stress in T. asahii as compared to R. mucilaginosa GSH (18.95 \pm 3.19$)$ and GSSG $(3.7 \pm 2.74) m M g-18$ level. Statistical analysis revealed significantly higher GSH/GSSG ratio in both strains. NPSH (29.84 \pm 0.54$)$ level in T. asahii was much higher than in $\mathrm{R}$. mucilaginosa (6.05 \pm 0.24$)$. Chromate reductase (ChR) was assayed and its activity was optimum at $50^{\circ} \mathrm{C}$ ( $\mathrm{pH} \mathrm{6)}$ in $\mathrm{T}$. asahii while $\mathrm{R}$. mucilaginosa showed higher activity at $30^{\circ} \mathrm{C}(\mathrm{pH} 7)$. Activity of both ChRs was enhanced in the presence of $\mathrm{Mg}, \mathrm{Na}$, Co and Ca but strongly inhibited by $\mathrm{Hg}$ cations. Cr(VI) uptake capabilities were ranged between 43-97\% in R. mucilaginosa and 35-88\% in T. asahii. One dimensional electrophoresis revealed enriched bands of cysteine rich metallothioneins suggesting some differential proteins could be overexpressed under Cr(VI) stress.
\end{abstract}

Key words: Trichosporon asahii, Rhodotorula mucilaginosa, wastewater, resistance, bioaccumulation

\footnotetext{
*Author for correspondence: rehman_mmg@yahoo.com
} 


\section{INTRODUCTION}

Chromium (Cr) is the 7th 19 most abundant element on earth that exists in several oxidation states from +2 to +6 with an average concentration of $100 \mathrm{ppm}$ [1]. $\mathrm{Cr}$ is widely used in chrome electroplating and finishing, leather tanning, textile dyeing, stainless steel welding, ferrochrome production, metal processing industries, corrosion inhibition in power plants, wood treatment, mining equipment, manufacturing of refractory materials, pigments, and in nuclear facilities [2,3]. $\mathrm{Cr}$ is regarded as a priority pollutant by the USEPA [4] which poses threat to humans and has been linked to genotoxicity, carcinogenicity, allergenicity and mutagenicity [57]. Industrial wastewaters contain both chromium and salt ions which have toxic effects on the microbial consortia [8]. Stable forms of chromium in nature can be either trivalent or hexavalent [9]. Hexavalent chromium compounds are comparatively more toxic than trivalent owing to higher solubility, rapid permeability through biological membranes and subsequent interaction with intracellular proteins and nucleic acids [10,11]. Trivalent chromium, an essential trace element, plays an important role in regulating fat and glucose metabolism and involve in proper functioning of insulin [12] in all living organisms. $\mathrm{Cr}(\mathrm{VI})$ is reduced partially to highly unstable $\mathrm{Cr}(\mathrm{V})$ radical inside the cells that generates oxidative stress through the production of reactive oxygen species (ROS), leading to carcinogenicity [13].

Microbial tolerance and reduction of $\mathrm{Cr}(\mathrm{VI})$ to $\mathrm{Cr}$ (III) is considered to be an effective and independent phenomena [14] of combating $\mathrm{Cr}(\mathrm{VI})$ pollution. Yeast biomass has the ability to accumulate variety of heavy metals to varying degrees under a wide range of external conditions [15]. $\mathrm{Cr}(\mathrm{VI})$ gets entered into the cell through non-specific sulfate transporters [16] by facilitated diffusion and a gradient between the two sides of the cell membrane is established by the metabolically active cells, which constantly reduce $\mathrm{Cr}(\mathrm{VI})$ to $\mathrm{Cr}$ (III) enzymatically (flavoenzymes) and non-enzymatically [glutathione (GSH), NADPH and ascorbate] [17]. Yeast's response to chromium involves various cellular processes such as redox reactions [18], interactions with cellular organelles, binding by cytosolic molecules [19], as well as formation of protein-DNA and Cr-DNA adducts, DNA strand breaks and DNA-DNA cross links [20,21]. Due to oxidative stress produced by $\mathrm{Cr}$, induction of stress proteins, $\mathrm{Cr}$ entrapment into membranous capsules, metal precipitation, chelation and active efflux were observed in other organisms [14], or were hypothesized to occur in yeast [22]. However, the detailed mechanisms regarding yeast-Cr interactions are yet unclear. In this study, $\mathrm{Cr}(\mathrm{VI})$ resistant yeasts, isolated from wastewater effluents were exposed to $100 \mathrm{mg} / \mathrm{L} \mathrm{Cr}(\mathrm{VI})$. Glutathione and NPSH contents in metal treated and untreated samples were also investigated. Chromate reductases (ChRs) involved in $\mathrm{Cr}(\mathrm{VI})$ reduction were assayed. The amount of chromium associated with cell surface, accumulated inside cell or present in the medium were assessed by atomic absorption spectrometer (AAS). Protein profiling was also studied by one dimentional (1DE) gel electrophoresis.

\section{MATERIALS AND METHODS}

\section{Isolation, Screening and Identification}

Wastewater samples were collected from the synthetic mills and industrial effluents of Sheikhupura, located near to Lahore and their physiochemical parameters viz., $\mathrm{pH}$ and temperature were noted. Cultures were maintained on Yeast Potato Dextrose (YPD) agar plates comprised of glucose $20 \mathrm{~g} / \mathrm{L}$, peptone $20 / \mathrm{g} \mathrm{L}$, yeast extract $10 / \mathrm{g} \mathrm{L}$ and agar $20 / \mathrm{g} \mathrm{L}$. Isolation was done by spreading $100 \mathrm{~mL}$ of wastewater samples on 
YPD agar plates. For screening, yeast isolates were aerobically grown in salt medium containing: $10 \mathrm{~g} / \mathrm{L}$ glucose, $1 \mathrm{~g} / \mathrm{L}$ (NH4)2SO4, $0.15 \mathrm{~g} / \mathrm{L} \mathrm{KH} 2 \mathrm{PO} 4,0.1 \mathrm{~g} / \mathrm{L}$ $\mathrm{K} 2 \mathrm{HPO} 4,0.1 \mathrm{~g} / \mathrm{L} \mathrm{MgSO} 4 \cdot 7 \mathrm{H} 2 \mathrm{O}, 0.026 \mathrm{~g} / \mathrm{L}$ FeSO 4 and $0.086 \mathrm{~g} / \mathrm{L} \mathrm{CaCl} 2$. The $\mathrm{pH}$ of the medium was adjusted to 7.0-7.2; medium was sterilized at $121^{\circ} \mathrm{C}$ for $20 \mathrm{~min}$, inoculated with yeast culture. The isolated strains were evaluated for their tolerance to $\mathrm{Cr}(\mathrm{VI})$ ions at different concentrations and highest resistance strains were selected for further experiments. Controls were treated identically but without heavy metal exposure.

DNA was isolated and polymerase chain reaction (PCR) was performed by 35 cycles of denaturation at $94^{\circ} \mathrm{C}$ for $4 \mathrm{~min}$, annealing at $55^{\circ} \mathrm{C}$ for $2 \mathrm{~min}$, and elongation at $72^{\circ} \mathrm{C}$ for $10 \mathrm{~min}$. PCR reaction mixture contained $3 \mu \mathrm{L}$ PCR buffer, $3 \mu \mathrm{L}$ dNTPs, 2.5 $\mu \mathrm{L}$ of each forward and reverse primer, $0.5 \mu \mathrm{L}$ taq polymerase, $2.5 \mu \mathrm{L} \mathrm{MgCl} 2,5 \mu \mathrm{L}$ nuclease free water and $6 \mu \mathrm{L}$ genomic DNA. The $18 \mathrm{~S}$ ribosomal RNA gene was cleaned by the thermo scientific geneJET gel extraction kit method and sequencing was performed.

\section{Survival to Heavy Metal Exposure}

Minimum inhibitory concentration was assessed by growing cultures on YPD agar plates with increasing concentrations of $\mathrm{K} 2 \mathrm{CrO} 7$ [23]. Grown yeast cells were subsequently transferred at a given concentration to next concentration and maximum resistance was evaluated until $T$. asahii and $R$. mucilaginosa cells were unable to grow as colonies on metal-containing agar plates. Any color changes of cultures in response to metal exposure were carefully noted.

\section{Quantification of GSH and NPSH}

Analysis of total glutathione (GSH) and non-protein thiol (NPSH) contents in cell lysates was estimated by the chemical method described by Israr et al. [24]. MSM broth medium $(100 \mathrm{~mL})$ was taken in $250 \mathrm{Ml}$ flask labelled as control and treatment and inoculated with $5 \times 106 / \mathrm{mL}$ of fresh pre-culture yeast cells followed by incubation at $30^{\circ} \mathrm{C}$ with constant agitation on shaker $(120 \mathrm{rpm})$. Cells were centrifuged at 1,400 $\mathrm{g}$ for $10 \mathrm{~min}$ and washed twice with $1 \mathrm{mM}$ phosphate-buffered saline (pH 7) to remove any traces of growth medium, weighed and suspended in 5\% $(\mathrm{w} / \mathrm{v})$ sulfosalicylic acid. Pellet was sonicated for $15 \mathrm{sec}$ with $60 \mathrm{sec}$ interval (5 cycles) and centrifuged at $11,000 \mathrm{~g}$ at $4^{\circ} \mathrm{C}$ for $10 \mathrm{~min}$. The lysate obtained was used to determine GSH and NPSH levels.

Quantification of GSH and GSSG levels was done by incubating the reaction contained reaction buffer (0.1M phosphate buffer of $\mathrm{pH} 7)$ and $0.5 \mathrm{mM}$ EDTA), crude extract and $3 \mathrm{mM}$ of 5 dithio-bis-( 2 nitrobenzoic acid) at $30^{\circ} \mathrm{C}$ for $5 \mathrm{~min}$ followed by addition of NADPH $(0.4 \mathrm{mM})$ and $2 \mu \mathrm{L}$ glutathione reductase (GR) enzyme. Samples were kept at $30^{\circ} \mathrm{C}$ for further $20 \mathrm{~min}$ to allow the reaction to complete and absorbance was taken at $412 \mathrm{~nm}$ by UV-vis spectrophotometer (Hitachi U-2800, Tokyo, Japan).

Glutathione level in the samples were compared with standard curve constructed by using various concentrations of reduced glutathione (GSH). GSH levels in the samples are expressed in $\mathrm{mM} / \mathrm{g}$ of cells.

Biomass prepared from oxidant free salt medium was taken as control.

NPSH were quantified by mixing $100 \mu \mathrm{L}$ of extracted sample (treated and untreated), $1 \mathrm{mM}$ of 5 dithio bis-(2-nitrobenzoic acid) and reaction buffer containing $0.1 \mathrm{M}$ phosphate buffer $(\mathrm{pH} 7)$ and $0.5 \mathrm{mM}$ EDTA. The reaction was completed by incubating reaction mixture at $30^{\circ} \mathrm{C}$ for $10 \mathrm{~min}$. A standard curve was prepared from varying concentrations of cysteine. Control was identically treated without exposure of heavy metal ions. 


\section{Determination of Intracellular Enzyme Activity}

Intracellular chromate reductase activity was estimated by collecting the cell pellet after centrifugation (1,500 $\mathrm{g}$ for $10 \mathrm{~min}$.) of culture, washing twice with sodium phosphate buffer ( $50 \mathrm{mM}, \mathrm{pH} 7.0)$ and lysing by sonication for $15 \mathrm{sec}$ with a $60 \mathrm{sec}$ interval $\left(5\right.$ cycles) at $4^{\circ} \mathrm{C}$. This sonicated suspension or cell free extract (CFE) was collected by centrifugation $(4,000 \mathrm{~g})$ for $10 \mathrm{~min}$ and used as a crude enzyme source for activity analysis. The protein concentration was determined by Bradford [25] assay using bovine serum albumin (BSA) as a standard.

ChR activity was determined by means of an enzyme assay comprised of crude enzyme, $0.1 \mathrm{mM}$ NADH and $20 \mu \mathrm{M} \mathrm{Cr}(\mathrm{VI})$ in $50 \mathrm{mM}$ potassium phosphate buffer of $\mathrm{pH}$ 6.0. The reaction was initiated by adding freshly prepared NADH as an electron donor and incubating the reaction mixture at $30^{\circ} \mathrm{C}$ for $30 \mathrm{~min}$ [26] and percentage relative activity of crude enzyme was calculated. Assay mixtures containing no enzyme or NADH were used as respective controls. One unit of chromate reductase activity is defined as the amount of enzyme that reduced one $\mu$ mole of $\mathrm{Cr}(\mathrm{VI})$ per min per ml under the assay conditions at $30^{\circ} \mathrm{C}$.

\section{Reduction of Hexavalent Chromium}

Reduction was estimated by measuring the decrease in hexavalent chromium in the culture filtrate by diphenylcarbazide (DPC) method [27]. The reaction mixture was kept at room temperature for 10 min for pink-violet colored complex formation in acidic solution and optical density was taken at $540 \mathrm{~nm}$.

\section{Effect of Temperature, $\mathrm{pH}$ and Metal Ions}

Chromate reductase was checked at selected temperatures of $30,40,50,70$ and $90^{\circ} \mathrm{C}$ by incubating the enzyme reaction mixture by the standard enzyme assay method. The $\mathrm{pH}$ profile of crude enzyme was determined by incubating enzyme over a $\mathrm{pH}$ range of 5-9 while keeping the reaction mixture at $30^{\circ} \mathrm{C}$ for $30 \mathrm{~min}$. For $\mathrm{pH}$ profile, buffer systems used were sodium acetate buffer; $\mathrm{pH}$ (5.0-6.0), sodium phosphate buffer; $\mathrm{pH}$ (7.0-8.0), and Tris-HCl buffer; $\mathrm{pH}$ (9.0). Reaction mixture without enzyme (control) was prepared under the same condition and was used to measure the possible changes in O.D. Different chloride metal salts in the form of $\mathrm{NaCl}$, $\mathrm{MgCl} 2, \mathrm{CoCl} 2, \mathrm{HgCl} 2$ and $\mathrm{CaCl} 2$ were selected to assess their effects on enzyme activity. A reaction mixture with no metal ion added in reaction was taken as control.

\section{Chromium Uptake Processes by Yeasts}

Cultures were grown in MSM medium, incubated under shaking condition (120 rpm) and aliquots $(5 \mathrm{~mL})$ were taken out under sterilized conditions after time interval of $2,4,6,8,10$, and 12 days. The samples were centrifuged at 4,000 $\mathrm{g}$ for $10 \mathrm{~min}$, collected culture pellets were weighted and washed thrice with autoclaved distilled water afterwards divided into two parts. One part was washed thrice with $0.1 \mathrm{M}$ EDTA for $10 \mathrm{~min}$. The amount of metal associated with the cell surface was removed as soluble fraction.

The second part [(acid digested; 0.2 N HNO3, H2SO4 (1:1)] was left on hot plate for half an hour. Total chromium content present in the medium or processed by the yeast cells was estimated by atomic absorption spectrometer (Zeeman AAS, Z-5000 Model, Hitachi Ltd, Japan) using flame (air-acetylene burner) at $359.3 \mathrm{~nm}[28,29]$.

\section{Metallothioneins Profiling}

One dimentional (1-DE) gel electrophoreses was performed on $14 \%$ polyacrylamide gels. Protein samples $(20 \mu \mathrm{g} / \mu \mathrm{L})$ were precipitated with an equal volume of $10 \%$ chilled TCA (v/v) and centrifuged at $11,000 \mathrm{~g}$ for $15 \mathrm{~min}$. Proteins were electrophoresed at a constant voltage $(120 \mathrm{~V})$ according to Laemmli [30]. 


\section{Statistical Analysis}

Three independent experiments were performed and data shown in this article was average values of means and \pm standard deviation (SD). Significance testing between samples was calculated by performing Student's $t$-test and analysis was done with the program statistical package for social sciences (SPSS) version 15. Control group was treated identically without exposure to any treatment.

\section{RESULTS AND DISCUSSION}

Yeasts isolated from metal polluted wastewater had a potential to survive well in heavy metal ions. A total of 16 yeasts were isolated and two of them were selected on the basis of higher chromium tolerance.

Both strains exhibiting higher $\mathrm{Cr}(\mathrm{VI})$ resistance were subjected to molecular identification. The nucleotide sequence similarities were determined using the basic local alignment search tool (http://www.ncbi.nlm.nih.gov/BLAST). Yeasts were identified as Rhodotorula mucilaginosa and Trichosporon asahii under accession number JQ966756 and KJ 913820.

\section{Minimum Inhibitory Concentration (MIC) and Color Change}

R. mucilaginosa and T. asahii showed maximum resistant to $\mathrm{Cr}(\mathrm{VI})$ up to $8 \mathrm{mM}$ and $6 \mathrm{mM}$, respectively. Recently, T. asahii can tolerate $\mathrm{NaAsO} 2$ and $\mathrm{CdCl} 2$ up to 30 $\mathrm{mM}$ and $10 \mathrm{mM}$, respectively [23]. C. tropicalis can tolerate $\mathrm{Cr}(\mathrm{VI})$ up to $5 \mathrm{mM}$ [31] in accord with our results. Wang et al. [32] stated that Rhodotorula sp. Y11 isolated from mine soil could survive $2000 \mathrm{mg} / \mathrm{L}$ cadmium. Biomass (Table 1) content in both strains was reduced as compared to the controls. The color of $T$. asahii mycelium and red yeast was affected by $\mathrm{Cr}(\mathrm{VI})$ and transformed to green with time course in comparison with the control simply due to the reduction or transformation of $\mathrm{Cr}(\mathrm{VI})$ in solution (Fig. 1). This color change may be due to yeast cells adapt and synthesize essential enzymes required for the accumulation and reduction of $\mathrm{Cr}(\mathrm{VI})$ to $\mathrm{Cr}$ (III).

Table 1. Gram fresh weight (biomass) of $R$. mucilaginosa and $T$. asahii grown in MSM supplemented with and without chromium.

\begin{tabular}{|l|c|c|c|c|}
\hline \multirow{2}{*}{ Sewage fungal isolates } & \multicolumn{4}{|c|}{ Fresh weight expressed as percentage (\%) } \\
\cline { 2 - 5 } & Sample 1 & Sample 2 & Sample 3 & $\begin{array}{c}\text { Mean } \pm \\
\text { SD }\end{array}$ \\
\hline $\begin{array}{l}\text { R. mucilaginosa } \\
\text { Control (without heavy } \\
\text { metal) } \\
\text { Medium with } \mathrm{K}_{2} \mathrm{Cr}_{2} \mathrm{O}_{7}\end{array}$ & 100 & 100 & 100 & 100 \\
\hline $\begin{array}{l}\text { T. asahii } \\
\text { mentrol (without heavy } \\
\text { Medium with } \mathrm{K}_{2} \mathrm{Cr}_{2} \mathrm{O}_{7}\end{array}$ & 100 & 100 & 100 & 100 \\
\hline
\end{tabular}

Three biological replicates were used and an equal gram weight was taken for protein extraction. 


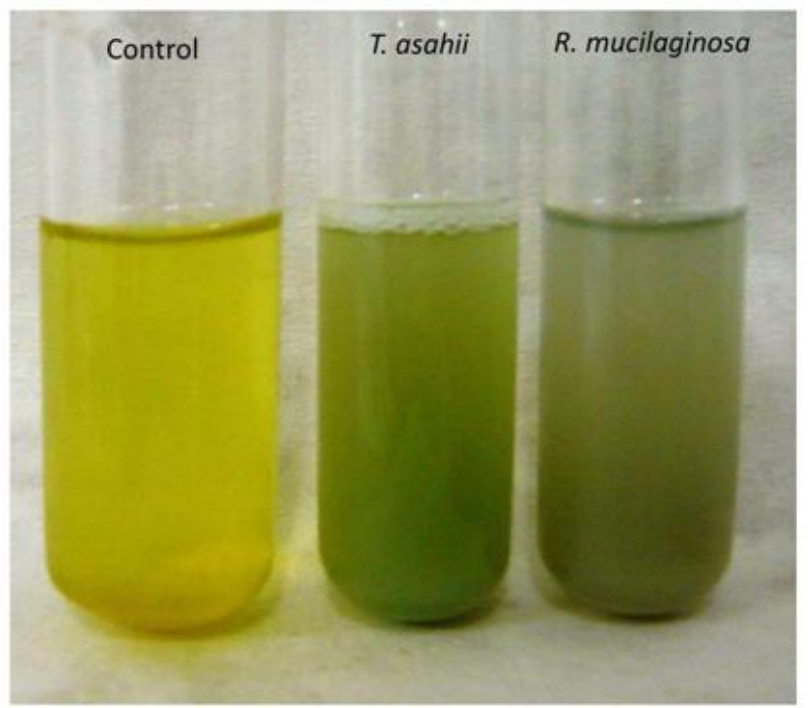

Fig 1 Hexavalent chromium reduction by $R$. mucilaginosa and T. asahii cells

\section{Growth Curves}

Slow growth pattern of $R$. mucilaginosa and $T$. asahii strains was observed under $\mathrm{Cr}(\mathrm{VI})$ stress. Growth rates (Fig. 2a, b) of both isolates were extended as compared to controls. C. intermedia showed extended lag growth phase at $50 \mathrm{mg} / \mathrm{L}$. Ilyas and Rehman [31] also observed extended lag phase of $C$. tropicalis cultures grown in medium containing heavy metal ions.

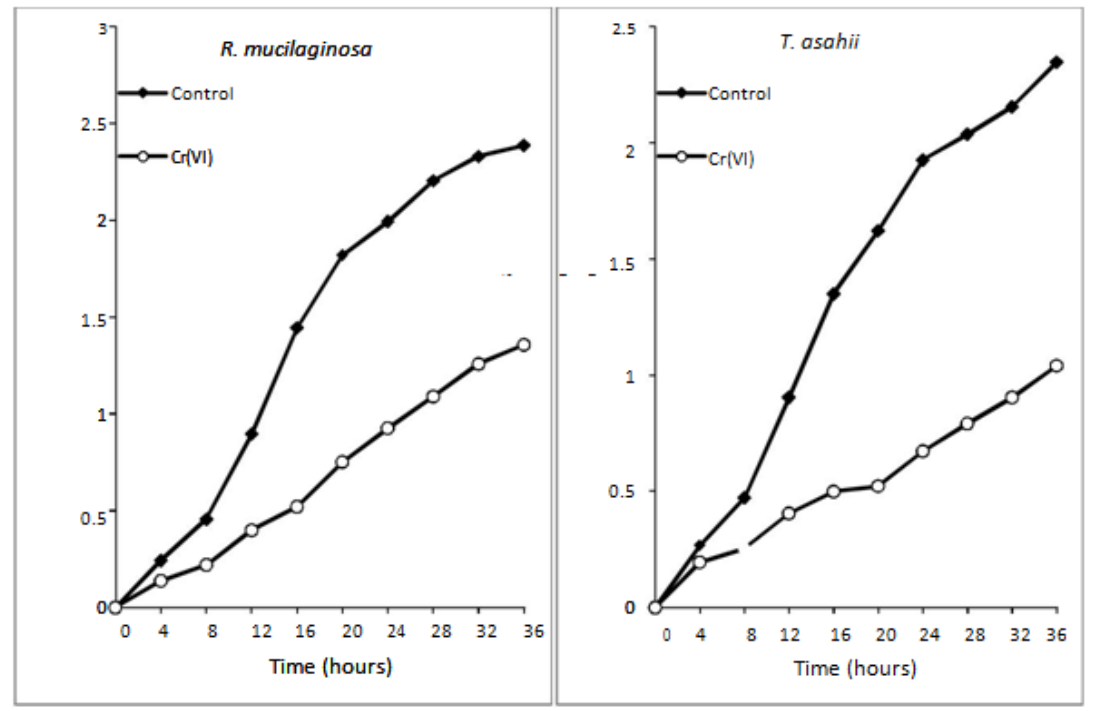

Fig 2 Growth curves for R. mucilaginosa and T. asahii with and without $\mathrm{Cr}(\mathrm{VI})$

\section{Quantification of GSH and NPSH}

Heavy metal exposure had resulted in increased GSH intracellular pool and this accumulation eventually transformed GSH/GSSG ratio. Remarkably elevated GSH $(69.88 \pm 10.01)$ and GSSG (11.24 \pm 0.96$)$ was observed under metal stress in $T$. asahii as compared to GSH $(18.95 \pm 3.19)$ and GSSG $(3.7 \pm 2.74) \mathrm{mM} / \mathrm{g} \mathrm{FW}$ in $R$. mucilaginosa (Table 2). Taking into account the total GSH concentration, more than two fold growths was observed under $\mathrm{K} 2 \mathrm{Cr} 2 \mathrm{O} 7$ stress in $T$. asahii as compared to $R$. mucilaginosa (Fig. 2a). The rise in regeneration of GSH in response to oxidative stress could be a significant determinant of cell survival. Previous studies have been revealed that increasing GSH synthesis through overexpression of GSHI augments 
the GSH pool by 50-66\% [33] and various metabolic processes lead to induction of enzymes involved in the GSH pathway [34]. GSSG, a potential toxicant, was detected at a very low concentration in normal cells than in stressed cells. GSH/GSSG ratio was also higher in much in $T$. asahii than in $R$. mucilaginosa $\mathrm{K} 2 \mathrm{Cr} 2 \mathrm{O} 7$ treated cells in agreement with reports of Peña-Llopis et al. [35]. Nonprotein thiol (NPSH) level was increased to $29.84 \pm 0.54$ in T. asahii and $6.05 \pm$ 0.24 in R. mucilaginosa (Table 2). Recently, Ilyas and Rehman [31] also reported an increased NPSH contents in $\mathrm{Cr}(\mathrm{VI})$ treated $C$. tropicalis.

Table 2. Intracellular levels of GSH, GSSG, total glutathione, GSH/GSSG ratio and NPSH in $R$. mucilaginosa and T. asahii with and without chromium.

\begin{tabular}{|c|c|c|c|c|c|}
\hline Yeast isolates & $\begin{array}{c}\text { GSH } \\
(\mathrm{mM} / \mathrm{g} \mathrm{FW})\end{array}$ & $\begin{array}{c}\text { GSSG } \\
(\mathrm{mM} / \mathrm{g} \mathrm{FW})\end{array}$ & $\begin{array}{l}\text { GSH+GSSG } \\
(\mathrm{mM} / \mathrm{g} \text { FW) }\end{array}$ & GSH/GSSG & $\begin{array}{c}\text { NPSH } \\
(\mathrm{mM} / \mathrm{g} \text { FW })\end{array}$ \\
\hline T. asahii without $\mathrm{K}_{2} \mathrm{Cr}_{2} \mathrm{O}_{7}$ & $36.83 \pm 2.12$ & $7.0 \pm 4.13$ & $43.83 \pm 6.25$ & $5.26 \pm 10.24$ & $13.0 \pm 0.013$ \\
\hline T. asahii with $\mathrm{K}_{2} \mathrm{Cr}_{2} \mathrm{O}_{7}$ & $69.88 \pm 10.01$ & $11.24 \pm 0.96$ & $81.12 \pm 10.97$ & $6.21 \pm 22.54$ & $29.84 \pm 0.54$ \\
\hline $\begin{array}{l}\text { R. mucilaginosa without } \\
\mathrm{K}_{2} \mathrm{Cr}_{2} \mathrm{O}_{7}\end{array}$ & $7.67 \pm 0.95$ & $1.77 \pm 0.36$ & $9.46 \pm 1.31$ & $4.32 \pm 2.5$ & $3.0 \pm 0.08$ \\
\hline $\begin{array}{l}\text { R. mucilaginosa with } \\
\mathrm{K}_{2} \mathrm{Cr}_{2} \mathrm{O}_{7}\end{array}$ & $18.95 \pm 3.19$ & $3.7 \pm 2.74$ & $22.65 \pm 5.93$ & $5.12 \pm 8.74$ & $6.05 \pm 0.24$ \\
\hline
\end{tabular}

Experiments were performed in triplicate $(n=3)$ and $\mathrm{p}<0.1$ where values were expressed as mean \pm SE.

\section{Chromium Reductase Assay}

Both the strains raised and induced the intracellular chromate reductase (ChR) activity by reducing $\mathrm{Cr}(\mathrm{VI})$ present in the culture medium. $R$. mucilaginosa showed 0.5 fold whereas T. asahii exhibited 0.35 fold increase in ChR activity when compared to controls (Fig. 3). Das and Chandra [36] noticed an increase in chromate reductase activity when working with $\mathrm{Cr}(\mathrm{VI})$ Streptomyces sp. M3 cultures. The enzymatic conversion of $\mathrm{Cr}(\mathrm{VI})$ to $\mathrm{Cr}(\mathrm{III})$ was reported in Candida maltose [37], Candida utilis [18] and fungi such as Hypocrea tawa [38] and Aspergillus sp. [39]. Microbes of the genera Pseudomonas, Arthrobacter, Escherichia and Bacillus have been reported to reduce $\mathrm{Cr}(\mathrm{VI})$ through soluble chromate reductase [40,41]. Negligible reduction was observed in controls (Fig. 1) indicating the role of yeast's enzymes in $\mathrm{Cr}(\mathrm{VI})$ reduction $[42,43]$. 


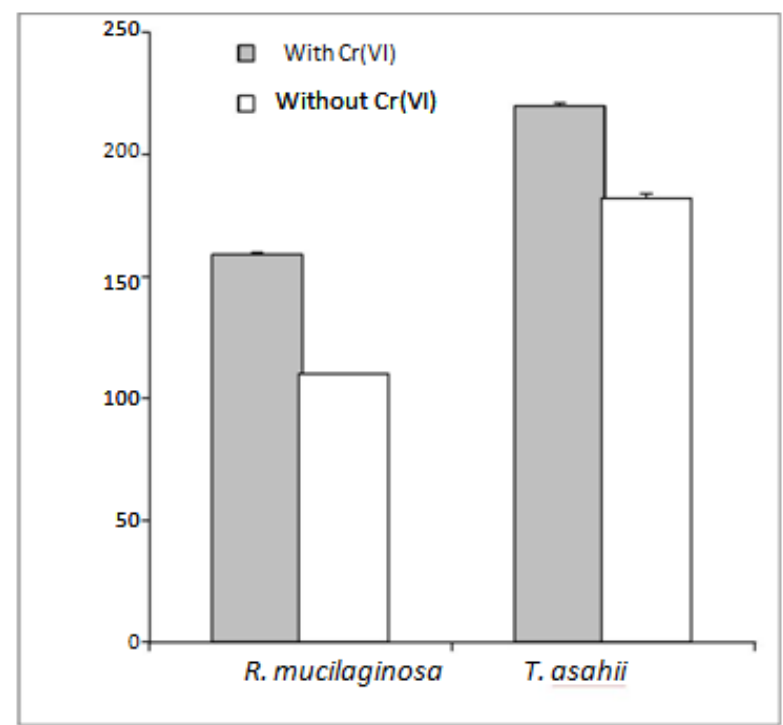

Fig 3 Relative specific activity of chromate reductase in $R$. mucilaginosa and $T$. asahii Values were expressed as mean of \pm SD where $* p=0.05$ and ${ }^{* *} p=0.1$ and all experiments were performed in triplicate

\section{Effect of Temperature, $\mathrm{pH}$ and Metal Ions on Enzyme Activity}

Effect of temperature in the range of $30-90^{\circ} \mathrm{C}$ was evaluated. ChR from $T$. asahii exhibited maximum activity at 500192 $\mathrm{C}$ while $R$. mucilaginosa showed higher chromate reductase at $30^{\circ} \mathrm{C}$ (Fig. 4a). Maximum chromate reductase activity observed by Pichia jadinii M9 and Pichia anomala M10 was 60 and $50^{\circ} \mathrm{C}$, respectively [44]. Among bacterial ChRs, the optimal temperature varies in the range $30-50^{\circ} \mathrm{C}[45,46]$.

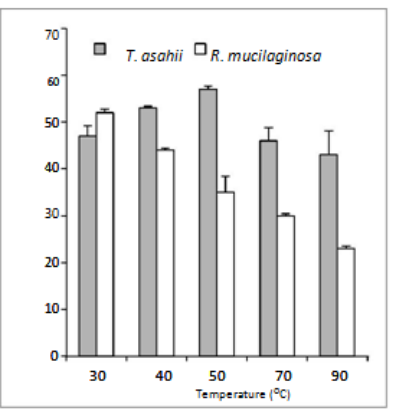

(a)

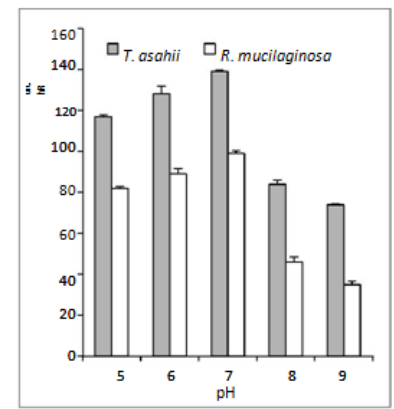

(b)

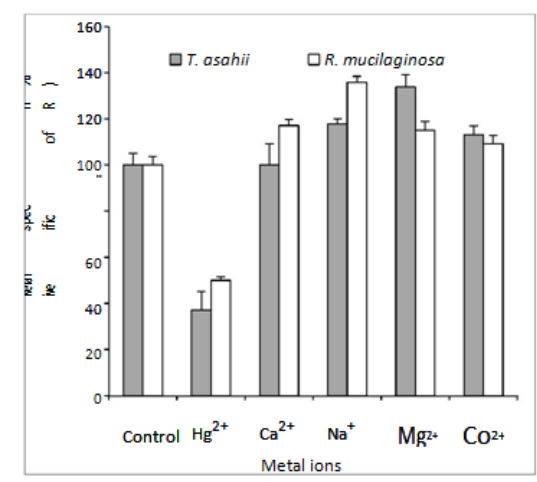

(c)

Fig 4 Effects of temperature (a) $\mathrm{pH}$ (b) and metal ions (c) on chromate reductase activity in R. mucilaginosa and $T$. asahii. Values were expressed as mean of \pm SD where ${ }^{*} p=0.05$ and $* * p=0.1$ and all experiments were performed in triplicate. 
$\mathrm{pH}$ is a major factor affecting efficiency of enzymes as acidic or strongly alkaline $\mathrm{pH}$ inactivates enzymes. Experiments were also conducted to elucidate whether $\mathrm{pH}$ affected chromate reductase activity and it was assessed that enzymatic activity was greatly affected changed due to $\mathrm{pH}$. Chromate reductase was moderately stable at $\mathrm{pH}$ range from 5-6 in $R$. mucilaginosa; nevertheless its optimum $\mathrm{pH}$ was 7 in sodium phosphate buffer (Fig. 4b). The ChR of $T$. asahii had a higher activity in sodium acetate buffer at $\mathrm{pH} 6$ which correlates with reports of Martorell et al. [44]. Chromate reductase activity was lost to $55 \%$ in $T$. asahii and $53 \%$ in $R$. mucilaginosa with increasing $\mathrm{pH}$ suggesting a decline in chromate reductase activity resulted with increasing $\mathrm{pH}$ values. At $\mathrm{pH}$ values above or below the optimum, a decline in enzyme activity was pronounced.

The presence of heavy metal ions in industrial effluents could potentially inhibit or enhance chromate reductase activity. The enzyme activity was also sensitive to metal ions (in buffer) and it was found that $\mathrm{Na}+$ enhanced enzyme activity to $36 \%$ while $\mathrm{Ca} 2+\mathrm{Mg} 2+$, and $\mathrm{Co} 2+$ activated the enzyme more modestly (Fig. 4c) in $R$. mucilaginosa. $\mathrm{Mg} 2+$ and $\mathrm{Ca} 2+$ enhanced chromate reductase in $T$. asahii to 34 and $17 \%$, respectively. Both strains showed negligible increase in enzyme activity on $\mathrm{Co} 2+$ addition. In this study relative chromate reductase activity was greatest when treated with $\mathrm{Na}+$ and $\mathrm{Mg} 2+$ but, interestingly, other divalent metal ions also showed increased enzyme activity suggesting the enzyme is not absolutely specific for $\mathrm{Na}+$ or $\mathrm{Mg} 2+$. Inhibition of enzyme activity by $\mathrm{Hg}$ ions was noticed which was higher (63\%) in T. asahii and reduced to (50\%) in R. mucilaginosa (Fig. 4c). These results agree with reports of Camargo et al. [47] and Elangovan et al. [46].

\section{Metal Uptake Potential of Yeasts}

$\mathrm{Cr}(\mathrm{VI})$ in the medium interact continuously with cell wall surface of the $R$. mucilaginosa yeast cells adsorbing 11.21, 14.81, 19.35, 23.07, 25.05 and 27.04 and accumulated $32.02,45.25,56.2162 .58,66.94$, and $70.07 \mathrm{mg} / \mathrm{g}$ efficiently after 2,4 , 6, 8, 10 and 12 days (Table 3). Chromium removal efficiency was ranged between 43-97\% (Fig. 5a) within 2 and 12 days suggesting the metal in the medium is processed enzymatically. T. asahii cells adsorbed 7.34, 11.05, 13.22, 16.28, 18.29, $21.01 \mathrm{mg} / \mathrm{g} 219$ and taken up 28.05, 34.21, 45.25, 55.09, 64.57 and $67.14 \mathrm{mg} / \mathrm{g}$ within 2 and 12 days of incubation (Table 3 ). The metal removal potential was 35$88 \%$ in $T$. asahii (Fig. 5b). These results clearly indicated that both strains are good candidates for accumulating and removing chromium from the environment although the metal removal efficiency of $R$. mucilaginosa is higher than that of $T$. asahii. Li and Yuan [48] reported maximal metal uptake value of $19.38 \mathrm{mg} / \mathrm{g}$ by Rhodotorula sp. Y11. The highest chromium adsorption by $R$. mucilaginosa and T. asahii indicated more binding sites on cell wall as well as their potential use as bio sorbent and effectiveness to remove $\mathrm{Cr}(\mathrm{VI})$ ions from wastewater. Yeasts can accumulate higher concentration of heavy metal ions by bioaccumulation process rather than biosorption. Yeast and fungal enzymes incorporate the toxic heavy metal ions by consuming them in their metabolic pathways and exploiting as carbon or energy source [49].

Table 3. Amounts of heavy metal ion chromium taken up and adsorbed by R. mucilaginosa and T. asahii.

\begin{tabular}{|c|c|c|c|c|}
\hline \multirow{2}{*}{ Time } & \multicolumn{2}{|c|}{ Uptake (mg/g) } & \multicolumn{2}{c|}{ Adsorption (mg/g) } \\
\cline { 2 - 5 } & R. mucilaginosa & T. asahii & R. mucilaginosa & T. asahii \\
\hline 2 & $32.02 \pm 3.12$ & $28.05 \pm 8.24$ & $11.21 \pm 2.85$ & $7.34 \pm 4.25$ \\
4 & $45.25 \pm 5.07$ & $34.21 \pm 3.91$ & $14.81 \pm 0.51$ & $11.05 \pm 0.07$
\end{tabular}




\begin{tabular}{|c|c|c|c|c|}
6 & $56.21 \pm 13.05$ & $45.25 \pm 9.01$ & $19.35 \pm 20.16$ & $13.22 \pm 4.14$ \\
8 & $62.58 \pm 0.21$ & $55.09 \pm 0.33$ & $23.07 \pm 1.21$ & $16.28 \pm 6.89$ \\
10 & $66.94 \pm 2.25$ & $64.57 \pm 1.62$ & $25.05 \pm 12.84$ & $18.29 \pm 0.65$ \\
12 & $70.07 \pm 0.21$ & $67.14 \pm 15.41$ & $27.04 \pm 0.25$ & $21.01 \pm 13.27$ \\
\hline
\end{tabular}

Experiments were performed in triplicate $(n=3)$ and $\mathrm{p}<0.1$ where values were expressed as mean \pm SE.

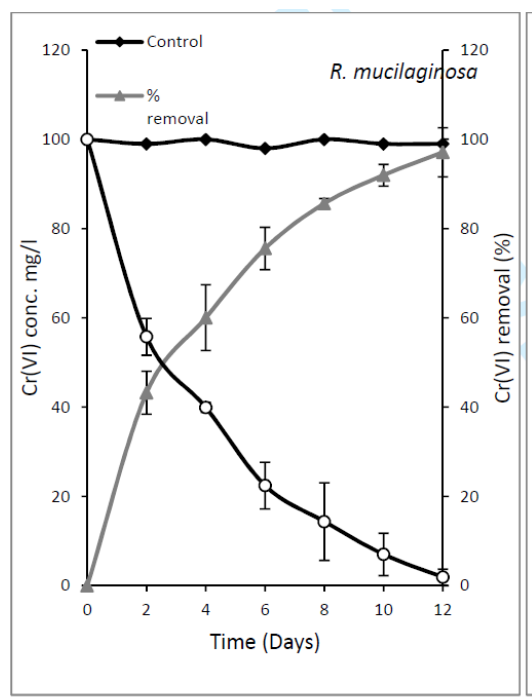

(a)

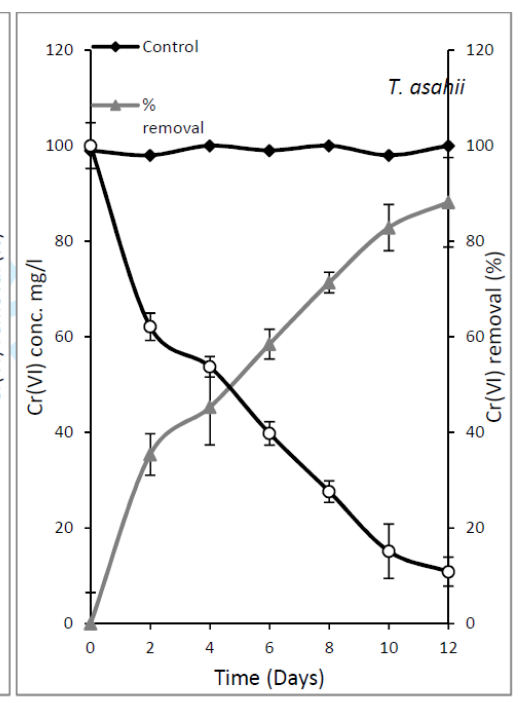

(b)

Fig 5 Estimated concentrations of chromium taken up and adsorbed by R. mucilaginosa and T. asahii yeast cells. Metal in the samples was assayed for metal estimation by using atomic absorption spectrophotometer (AAS). Controls contained heavy metal ions but did not contain yeast cells.

The heavy metals $(\mathrm{Cd}, \mathrm{Cu}, \mathrm{Pb})$ uptake by consortium of fungi, Penicillium sp. A1 and Fusarium sp. A19 was significantly higher as revealed by Pan et al. [50]. The maximum biosorption capacity of macro fungus, Amanita rubescens determined was $27.3 \mathrm{mg} / \mathrm{g}$ for Cd [51]. Engineered Saccharromyces cerevisiae cells have been shown enhanced arsenite accumulation by overexpression of transporters responsible for metal influx [52]. Biosorption and uptake are mainly used to treat water containing variety of metal ions although these processes may be influenced and affected by the presence of other metal ions. The bioaccumulation processes revealed by yeasts are inexpensive and environment friendly methodology to remove dissolved heavy metal ions from the wastewater before its use in agriculture for irrigation purposes or discharge into the water bodies.

\section{Metallothioneins Profiling}

Expression of proteins in metal treated and untreated cultures were explored by one dimentional (1-DE) gel electrophoresis. Known protein concentration $(20 \mu \mathrm{g} / \mu \mathrm{L})$ was used and most of the differentially expressed protein bands were seen in yeast cultures exposed to chromium. Chromium treated $R$. mucilaginos a showed increased intensity of 16 and $22 \mathrm{kDa}$ bands which were much weaker in control and some additional proteins were also induced under stress conditions (Fig. 6). Likewise, in $T$. asahii, stronger 45 and $30 \mathrm{kDa}$ protein bands were induced by $\mathrm{Cr}$ (Fig. 8). Protein banding patterns revealed different intensities between control and treatments although overall protein loadings were equivalent. 


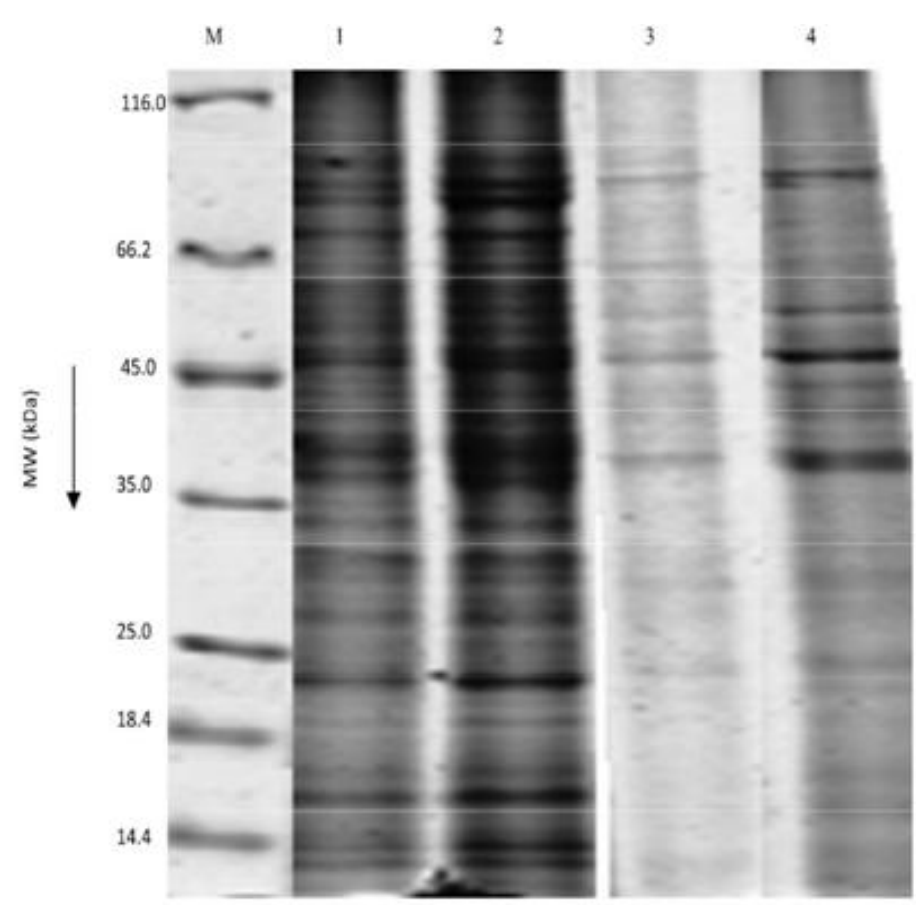

Fig 6 SDS-PAGE analysis of total proteins extracted from $R$. mucilaginosa and T. asahii stained with Coomassie blue R-250. Lane M, protein maker; lane 1 and 2 are showing control and $\mathrm{Cr}$ treated $R$. mucilaginosa; and lane 3 and 4 illustrate control and $\mathrm{Cr}$ treated T. asahii, respectively

Low molecular weight metallothioneins (MTs) were abundant in all chromium treated samples implying the possible role of in protection and survival of fungi against metal oxidative stress. Certain bands appeared in treatment were absent in control, especially lower molecular weight proteins in the mass range of $<20 \mathrm{kDa}$ with increased intensity observed in metal-treated samples.

\section{CONCLUSION}

In conclusion, wastewater yeasts, $R$. mucilaginosa and $T$. asahii, showed considerable resistance towards hexavalent chromium. Remarkably elevated GSH and GSH/GSSG ratio was observed under metal stress in T. asahii as compared to $R$. mucilaginosa. NPSH contents were also enhanced under Cr(VI) stress.

Chromium reductases (ChRs) isolated exhibit maximum activity at $30^{\circ} \mathrm{C}(\mathrm{pH} 7)$ in $R$. mucilaginosa and $50^{\circ} \mathrm{C}(\mathrm{pH} 6)$ in $T$. asahii. The activity pattern was not affected to higher extent in the presence of metal ions. Cr (VI) was absorbed and adsorbed by the yeast cells and reduced to $\mathrm{Cr}$ (III) by the chromate reductase (ChR). Certain bands present in controls were absent in treatments and the production of low molecular weight MTs were abundant in metal induced samples. Current investigation clearly demonstrated that yeast strains isolated have a strong potential to reduce toxic and soluble $\mathrm{Cr}$ (VI) to the less toxic and insoluble $\mathrm{Cr}(\mathrm{III})$ and hence can be employed as a biosorbant for $\mathrm{Cr}(\mathrm{VI})$ detoxification from the contaminated effluents

\section{COMPETING INTERESTS}

We declare that we have no competing interests.

\section{REFERENCES}


1- Emsley J. Chromium. Nature's building blocks: An A-Z guide to the elements. Oxford, England, UK. Oxford University Press. 2001; 495-498.

2- Juvera-Espinosa J, Morales-Barrera L, Cristiani-Urbina E. Isolation and characterization of a yeast strain capable of removing Cr(VI). Enz Microbial Technol. 2006; 40: 114-121.

3- Ibrahim ASS, Mohamed AE, Yahya BE, Al-Salamah AA, Garabed A. Hexavalent chromium reduction by alkaliphilic Amphibacillus sp $\mathrm{KSUCr} 3$ is mediated by copperdependent membrane associated chromate reductase. Extremophiles 2012; 16(4): 659668.

4- United State Environmental Protection Agency (USEPA), 2004. Cleaning Up the Nations Waste Sites: Markets and Technology Trends. EPA, 542-R-04-015

5- Dayan AD, Paine AJ. Mechanisms of chromium toxicity, carcinogenicity and allergenicity: review of the literature from 1985 to 2000. Human Expl Toxicol. 2001; 20: 439-451.

6- Thacker U, Parikh R, Shouche Y, Madamwar D. Reduction of chromate by cell-free extract of Brucella sp. isolated from Cr(VI) contaminated sites. Bioresour Technol. 2007; 98(8): 1541-1547.

7- Thompson CM, Fedorov Y, Brown DD, Suh M, Proctor DM, Kuriakose L, Harris MA. Assessment of $\mathrm{Cr}(\mathrm{VI})$-induced cytotoxicity and genotoxicity using high content analysis. PloS One 2012; 7(8): e42720.

8- Stasinakis AS, Thomaidis NS, Mamais D, Papanikolaou EC, Tsakon A, Lekkas TD. Effect of chromium (VI) addition on the activated sludge process. Water Res. 2003; 37: 2140 2148.

9- Bai Z, Harvey LM, McNeil B. Oxidative stress in submerged cultures of fungi. Crit Rev Biotechnol. 2003; 284 23: 267-302.

10- Anderson RA. Chromium as an essential nutrient for humans. Reg Toxicol Pharmacol. 1997; 26: 35-41.

11- Kotas J, Stasicka Z. Chromium occurrence in the environment and methods of its speciation. Environ Poll. 2000; 107: 263-283.

12- Anderson RA, Polansky MM, Bryden NA. Stability and absorption of chromium and absorption of chromium histidinate complexes by humans. Biol Trace Elem Res. 2004; 101(3): 211-218.

13- Ackerley DF, Barak Y, Lynch SV, Curtin J, Matin A. Effect of chromate stress on Escherichia coli K-12. J Bacteriol. 2006; 188: 3371-3381.

14- Cervantes C, Campos- García J, Devars S, Gutiérrez- Corona F, Loza- Tavera H, Torres- Guzmán JC, Moreno- Sánchez R. Interactions of chromium with microorganisms and plants. FEMS Microbiol Rev. 2001; 25(3): 335-347.

15- Villegas LB, Amoroso MJ, De Figueroa LIC. Copper tolerant yeasts isolated from polluted area of Argentina. J Basic Microbiol. 2005; 45: 381-391.

16- Wiegand HJ, Ottenweilder H, Bolt HM. Fast uptake kinetics in vitro of $51 \mathrm{Cr}$ (VI) by red blood cells of man and rat. Arch Toxicol. 1985; 57: 31e34.

17- Pesti M, Gazdag Z, Belágyi J. In vitro interaction of trivalent chromium with yeast plasma membrane, as revealed by EPR spectroscopy. FEMS Microbiol Lett. 2000; 182: $375 \mathrm{e} 380$.

18- Muter O, Patmalnieks A, Rapoport A. Interrelations of the yeast Candida utillis: metal reduction and its distribution in the cell and medium. Process Biochem. 2001; 36: 963970.

19- Batic M, Raspor P. Uptake and bioaccumulation of $\mathrm{Cr}$ (III) in yeast Saccharomyces cerevisiae. Food Technol Biotechnol. 1998; 36: 291-297.

20- Cheng L, Liu S, Dixon K. Analysis of repair and mutagenesis of chromium induced damage in yeast, mammalian cells and transgenic mice. Environ Health Perspect. 1998; 106: 1027-1032.

21- Zahoor A, Rehman A. Isolation of Cr(VI) reducing bacteria from industrial effluents and their potential use in bioremediation of chromium containing wastewater. J Environ Sci. 2009; 21: 814-820.

22- Raspor P, Batic M, Jamnik P, Josic D, Milacic R, Pas M, Recek M, Rezic-Dereani V, Skrt M. The influence of chromium compounds on yeast physiology (a review). Acta Microbiol Immunol Hung. 2000; 47: 143-173. 
23- Ilyas S, Rehman A, Varela, AC, Sheehan, D. Redox proteomics changes in the fungal pathogen Trichosporon asahii on arsenic exposure: Identification of protein responses to metal-induced oxidative stress in an environmentally-sampled isolate. PloS One 2014; 9(7): e102340.

24- Israr M, Sahi SV, Jain J. Cadmium accumulation and antioxidant responses in the Sesbania drummondii callus. Arch Environ Contam Toxicol. 2006; 50: 121-127.

25- Bradford MM. Rapid and sensitive method for the quantitation of microgram quantities of protein utilizing the principle of protein-dye binding. Ann Biochem. 1976; 72: 248254.

26- Sarangi A, Krishnan C. Comparison of in vitro Cr (VI) reduction by CFEs of chromate resistant bacteria isolated from chromate contaminated soil. Bioresour Technol. 2008; 99(10): 4130-4137.

27- Apha. Standard methods for the examination of water and wastewater, 19th edn. American Public Health Association, Washington, DC. 1995.

28- Li ZJ, Yuan HL, Hu XD. Cadmium-resistance in growing Rhodotorula sp Y11. Bioresour Technol. 2008; 99:1339-1344.

29- Rehman A, Anjum MS. Cadmium uptake by yeast, Candida tropicalis, isolated from industrial effluents and its potential use in wastewater clean-up operations. Water Air Soil Pollut. 2010; 205: 149-159.

30- Laemmli UK. Cleavage of structural proteins during assembly of the head of the bacteriophage T4. Nature 1970; 227: 680-685.

31- Ilyas S, Rehman A. Oxidative stress, glutathione level and antioxidant response to heavy metals in multi resistant pathogen, Candida tropicalis. Environ Monitor Assess. 2015; 187: 4115. DOI: 10.1007/s10661-014-4115-9.

32- Wang PC, Mori T, Komori K, Sasatsu M, Toda K, Ohtake H. Isolation and characterization of an Enterobacter cloacae strain that reduces hexavalent chromium under anaerobic conditions. Appl J Environ Microbiol. 1989; 55: 1665-1669.

33- Cuozzo JW, Kaiser CA. Competition between glutathione and protein thiols for disufide bond formation. Nat Cell Biol. 1999; 1: 130-135.

34- Vido K, Spector D, Lagniel G, Lopez S et al. A proteome analysis of the cadmium response in Saccharomyces cerevisiae. J Biol Chem. 2001; 276: 8469-8474.

35- Pe na-Llopis S, Ferrando M.D, Pe na JB. Impaired glutathione redox status is associated with decreased survival in two organophosphate poisoned marine bivalves. Chemosphere 2002; 47: 485-497.

36- Das A, Chandra AL. Chromate reduction in Streptomyces. Experientia 1990; 46: $731 \mathrm{e} 733$.

37- Ramirez-Ramirez R, Calvo-Mendez C, Avila-Rodriguez M, Lappe P, Ulloa M, VazquezSuarez R, Gutierrez-Corona F. Cr(VI) reduction in a chromate resistant strain of Candida maltosa isolated from the leather industry. Anton Leeuw. 2004; 85: 63-68.

38- Morales-Barrera L, Guillén-Jimenéz FM, Ortiz-Moreno A, Villegas- Garrido TL, Sandoval-Cabrera A, Hernéndez-Rodríguez $\mathrm{CH}$, Cristiani-Urbina E. Isolation, identification and characterization of a Hypocrea tawa, strain with high $\mathrm{Cr}(\mathrm{VI})$ reduction potential. Biochem Eng J. 2008; 40: 284-292.

39- Srivastava S, Thakur IS. Isolation and process parameter optimization of Aspergillus sp. for removal of chromium from tannery effluent. Bioresour Technol. 2006; 97: 11671173.

40- Desai C, Jain K, Madamwar D. Hexavalent chromate reductase activity in cytosolic fractions of Pseudomonas sp. G1DM21 isolated from $\mathrm{Cr}(\mathrm{VI})$ contaminated industrial landfill. Process Biochem. 2008; 43: 713-721.

41- Elangovan R, Philip L, Chandraraj K. Hexavalent chromium reduction by free and immobilized cell-free extract of Arthrobacter rhombi-RE. Appl Biochem Biotechnol. 2010; 160: 81-97.

42- He M, Li X, Guo L, Miller S, Rensing C, Wang G. Characterization and genomic analysis of chromate resistant and reducing Bacillus cereus strain SJ1. BMC Microbiol. 2010; 10: 221.

43- Masood F, Malik A. Hexavalent chromium reduction by Bacillus sp. strain FM1 isolated from heavy metal contaminated soil. Bull Environ Contam Toxicol. 2011; 86(1): 114-119. 
44- Martorell MM, Fernández PM, Fariña JI, Figueroa LI. Cr (VI) reduction by cell-free extracts of Pichia jadinii and Pichia anomala isolated from textile-dye factory effluents. Int Biodeter Biodeg. 2012; 71: 80-85.

45- Bae WC, Lee HK, Choe YC, Jahng DJ, Lee SH, Kim SJ, Lee JH, Jeong BC. Purification and characterization of NADPH dependent $\mathrm{Cr}(\mathrm{VI})$ reductase from Escherichia coli ATCC 33456. J Microbiol. 2005; 43: 21-27.

46- Elangovan R, Abhipsa S, Rohit B, Ligy P, Chandraraj K. Reduction of Cr(VI) by a Bacillus sp. Biotechnol Lett. 2006; 28: 247-252.

47- Camargo FAO, Bento FM, Okeke BC, Frankenberger WT. Hexavalent chromium reduction by an Actinomycete, Arthrobacter crystallopoietes ES 32. Biol Trace Elem Res. 2004; 97: 183e194.

48- Li ZJ, Yuan HL. Characterization of cadmium removal by Rhodotorula sp Y11. Appl Microbiol Biotechnol. 2006; 73: 458-463.

49- Malik A. Metal bioremediation through growing cells. Environ Int. 2004; 30(2): 261-278.

50- Pan R, Cao L, Zhang R. Combined effects of $\mathrm{Cu}, \mathrm{Cd}, \mathrm{Pb}$, and $\mathrm{Zn}$ on the growth and uptake of consortium of Cu-resistant Penicillium sp. A1 and Cd-resistant Fusarium sp. A19. J Hazard Mater. 2009; 171(1): 761-766.

51- Sari A, Tuzen M. Kinetic and equilibrium studies of biosorption of $\mathrm{Pb}$ (II) and $\mathrm{Cd}$ (II) from aqueous solution by macrofungus (Amanita rubescens) biomass. J Hazardous Mater. 2009; 164(2): 1004-1011.

52- Shah D, Shen MW, Chen W, Da Silva NA. Enhanced arsenic accumulation in Saccharomyces cerevisiae overexpressing transporters Fps1p or Hxt7p. J Biotechnol. 2010; 150(1): 101-107. 